\title{
Effects of Salicornia herbacea Powder on Quality Traits of Sun-Dried Hanwoo Beef Jerky during Storage
}

\author{
Dong-Gyun Lim ${ }^{1}$, Kap-Sung $\mathrm{Choi}^{2}$, Jong-Ju Kim³ ${ }^{3}$, and Ki-Chang Nam* \\ Department of Animal Science and Technology, Sunchon National University, Suncheon 540-950, Korea \\ ${ }^{1}$ Department of Health Administration, Jinju Health College, Jinju 660-757, Korea \\ ${ }^{2}$ Department of Food Science and Technology, Sunchon National University, Suncheon, 540-950, Korea \\ ${ }^{3}$ School of Biotechnology, Yeungnam University, Gyeongsan 712-749, Korea
}

\begin{abstract}
The objective of this study was to evaluate the quality characteristics of sun-dried Hanwoo beef jerky added with Salicornia herbacea $(\mathrm{SH})$. Sliced Hanwoo beef shank were marinated and sun-dried at $28-30^{\circ} \mathrm{C}$, relative humidity (RH) $30-35 \%$ for $3.5 \mathrm{~h}$. The physicochemical and microbiological traits of the Hanwoo beef jerky were analyzed during the aerobically packaged storage at $25^{\circ} \mathrm{C}$. The water activities of beef jerky with $0.5 \%$ and $1.0 \%$ SH were lower than those of the control at $0 \mathrm{~d}$ $(p<0.05)$. The $\mathrm{pH}$ values of beef jerky with SH were significantly higher than those of the control $(p<0.05)$. The beef jerky with SH and ascorbic acid showed significantly lower TBARS values than the control $(p<0.05)$. The beef jerky with SH showed a significantly lower redness $\left(\mathrm{a}^{*}\right)$ than the control $(p<0.05)$. Total plate count (TPC) of beef jerky with $1.0 \% \mathrm{SH}$ was significantly lower than that of the control during the storage of $20 \mathrm{~d}(p<0.05)$. Yeast/mold was detected in the control and beef jerky with SH after storage periods of 10 and $20 \mathrm{~d}$, but was not detected in jerky with ascorbic acid. With regard to the sensory properties, beef jerky with SH showed significantly greater flavor scores than the others $(p<0.05)$. The result shows that $\mathrm{SH}$ powder can be used to increase the sensory quality and microbial safety of beef jerky.
\end{abstract}

Key words: beef jerky, sun-dried, Salicornia herbacea, quality, microbial safety

\section{Introduction}

Jerky is a food that has been prepared by humans at least since ancient Egyptian times. It derived from the Spanish word "charqui" and is classified by the U.S. Department of Agriculture (USDA) as a heat-treated and shelf-stable ready-to-eat meat product (USDA-FSIS, 2011). As a meat product, beef jerky is nutritious and shelf-stable due to its low water content, resulting in its high demand as a snack food (Calicioglu et al., 2003). Although the moisture content of beef jerky is low, there are still microbial safety problems during marketing and distribution in Korea, as well as worldwide (Park et al., 2009). Therefore, the efficacy of pretreatment on the inactivation of foodborne pathogens in the beef jerkymaking process should be investigated. Jerky is preserved by curing and drying to reduce water activity and control

\footnotetext{
*Corresponding author: Ki-Chang Nam, Department of Animal Science and Technology, Sunchon National University, Suncheon 540-742, Korea. Tel: 82-61-750-3231, Fax: 82-61-750-3230, E-mail: kichang@scnu.ac.kr
}

microbial survival and growth (Choi et al., 2008).

Drying is the world's oldest and most common method of food preservation in production of meat and meat products. By drying, the meat products such as jerky reach $a_{w}$ of $0.6-0.9$ equivalent to a $\mathrm{RH}$ of $60-90 \%$ at ambient temperature and the growth of microorganisms can be efficiently inhibited by a low $\mathrm{a}_{\mathrm{w}}$ system (Chang et al., 1996). There are several types of drying methods in the process of making jerky. For example, natural drying, hot and cold air-drying, vacuum drying, freeze-drying and so on can be used (Kim, 1990; Labelle and Moyer, 1966). Two types of natural drying are used mainly, which is sun and shade drying as traditional system. Traditional sun-drying process could be very time-consuming in drying and hard to control moisture contents (Lee et al., 2004). Hot air-drying from an artificial heat source is commonly used in the meat processing plants and done by placing food in either a warm oven or a food dehydrator (USDA-FSIS, 2011). This drying method is useful to inhibit the growth of microorganisms by lowering moisture contents during the hot air-drying process and prompt-dried evenly (Kim, 1990; Labelle and Moyer, 
1966). However, it has some disadvantages of not only surface hardening by this rapid drying and deterioration in meat quality such as flavor and texture due to maillard reaction (Labelle and Moyer, 1966), but also it is more susceptible to lipid oxidation and meat color with increasing drying time and temperature (Kim, 1990). So far, there have been few attempts to assess the quality and microbiological aspects of Hanwoo beef jerky produced under different drying conditions.

Lipid oxidation can have negative effects on the meat quality causing changes in sensory attributes (color, texture, odor, and flavor) and nutritional quality. Synthetic antioxidants such as butylated hydroxyanisole (BHA) and butylated hydroxytoluene (BHT) have been widely used in meat to suppress or retard the lipid oxidation (Chastain et al., 1982). However, the use of synthetic antioxidants has come under more scrutiny due to their potential toxicological effects (Rababah et al., 2004). Consumer preferences for natural products have resulted in increased interest in the use of natural antioxidants. Recently, there is a growing interest in searching for natural antioxidants due to their lower toxicities than synthetic antioxidants (Kim et al., 2012). Salicornia herbacea (SH) has been known as glasswort and distributed in salt marshes and muddy seashores along the Western coast of Korea (Chung et al., 2005). This plant, which is called 'hamcho' and 'tungtungmadi' in Korean, is consumed in a variety of ways such as a seasoned vegetable, salad, and fermented food in coastal areas of Korea (Kim et al., 2010). The whole plant is greedily devoured by cattle for its salty taste. It has been used as a traditional medicine for disorders such as constipation, obesity, diabetes, and cancer (Bang et al., 2002). SH (also known as glasswort) is annual succulent herb of chenopodiaceae family and one of the most salt tolerant plants (Kim et al., 2012). It contains large amounts of salts and minerals such as magnesium, calcium, potassium, and iron (Cho et al., 2008). It also contains large amounts of betaine and choline. The beneficial effects of consuming SH may be in part due to betaine or choline absorption (Shin et al., 2002).

Recently, the consumption of the plants has been extended into the functional food and medicinal plant due to its beneficial effects (Cho et al., 2008). A number of investigators have reported anti-oxidative, immunomodulatory, anti-hyperglycemic, and anticancer activities of SH (Lee et al., 2006), although there are a few references that may explain scientific base for its claimed therapeutic use. SH powders have recently been shown to reduce serum cholesterol and lipid contents in rats when fed with drinking water (Jo et al., 2002).

However, studies on the physiochemical traits of sundried beef jerky added with natural antioxidant plant such as SH have rarely been reported. Therefore, the aim of the study was to investigate the effects of SH powder on the physicochemical quality and microbiological safety in sun-dried Hanwoo (Korean native cattle) beef jerky during storage.

\section{Materials and Methods}

\section{Preparation of beef jerky}

Four fresh Hanwoo beef shank muscles were purchased from local retail shops (Goheung, Korea) to make 4-replication and were frozen at $-45^{\circ} \mathrm{C}$. After thawed until the internal temperature reached to $-1^{\circ} \mathrm{C}$ in the refrigerator prior to $1 \mathrm{~d}$, beef samples were sliced to $0.5 \mathrm{~cm}$-thick pieces with a meat slicer (HFS 350G, Hankook Fugee, Korea). The sliced jerky samples were cut parallel in direction to muscle fibers and all subcutaneous and intermuscular fat and visible connective tissue were removed from the muscles. The formulation for the production of Hanwoo beef jerky is presented in Table 1.

Four different beef jerky formula including $0 \%$ (control), $0.5 \% \mathrm{SH}$ powder, $1.0 \% \mathrm{SH}$ powder, and $0.5 \%$ ascorbic acid were prepared. Ascorbic acid was used to compare the anti- oxidative activities of $\mathrm{SH}$ in beef jerky. The SH powder was prepared by drying at $50^{\circ} \mathrm{C}$ for $48 \mathrm{~h}$ and passed through 100 mesh sieve. The sliced beef samples were submerged for $24 \mathrm{~h}$ in a curing liquid. The cured samples were then mixed using a mixer $(5 \mathrm{~K} 5 \mathrm{SS}$, KitchenAid, USA) for $1 \mathrm{~min}$ and aged for $24 \mathrm{~h}$ in refrigerated temperature. All cured muscles samples put on netted tray were sun-dried in the open sunny spot with air breezes at $28-30^{\circ} \mathrm{C}$, finally containing around relative humidity $(\mathrm{RH})$ $30-35 \%$ for $3.5 \mathrm{~h}$ until $\mathrm{a}_{\mathrm{w}}$ reached below 0.75 . All dried samples were then stored in a desiccator at room temperature until used for further analysis. The jerky samples were loosely packed in oxygen impermeable plastic bags and displayed at room temperature for up to $20 \mathrm{~d}$.

\section{Moisture contents and water activity}

Moisture content was obtained with a slightly modified method of AOAC methods (AOAC, 2000). The total moisture content of $3 \mathrm{~g}$ of finely chopped samples placed in aluminum moisture dishes were determined from their pre-dry and dry weights (dried in an air oven at $104^{\circ} \mathrm{C}$ for $24 \mathrm{~h}$ ) and expressed as the percentage of pre-dry weight and gram water per gram dry weight. The moisture con- 
Table 1. Formula for the preparation of Hanwoo beef jerky added with Salicornia herbacea extracts

\begin{tabular}{ccccc}
\hline \hline Ingredient & \multicolumn{4}{c}{ Treatment $(\mathrm{g})$} \\
\cline { 2 - 5 } & Control & Salicornia herbacea $0.5 \%$ & Salicornia herbacea $1.0 \%$ & Ascorbic acid $0.5 \%$ \\
\hline Beef & 400 & 400 & 400 & 400 \\
Water & 48 & 48 & 48 & 48 \\
Sodium chloride & 14 & 14 & 8 & 8 \\
Brown sugar & 8 & 8 & 0.2 & 0.2 \\
Sodium nitrite & 0.2 & 0.2 & 0.4 & 0.4 \\
Phosphates & 0.4 & 0.4 & 1.2 & 1.2 \\
Ginger powder & 1.2 & 1.2 & 1.2 & 1.2 \\
Onion powder & 1.2 & 1.2 & 1.2 & 1.2 \\
Garlic powder & 1.2 & 1.2 & 0.64 & 0.64 \\
Black pepper & 0.64 & 0.64 & 4 & 2 \\
Salicornia herbacea & & 2 & & \\
Ascorbic acid & & & & \\
\hline
\end{tabular}

tent was determined in triplicate on each jerky product. Three piece of the dried jerky samples from each treatment were selected and cut into small pieces using sharp scissors and were homogenized prior to measurement of water activity. The pieces were put into cups, and their water activities determined with a water activity meter (BT-RS1, Rotronic, Switzerland), calibrated at ambient temperature $\left(25^{\circ} \mathrm{C}\right)$ with distilled water $\left(\mathrm{a}_{\mathrm{w}}=0.999\right)$.

\section{pH}

The $\mathrm{pH}$ of samples was determined with a $\mathrm{pH}$ meter (Orion 2 Star, Thermo scientific, USA). The $\mathrm{pH}$ values of jerky were measured by blending a $3 \mathrm{~g}$ sample with 27 $\mathrm{mL}$ distilled water for $60 \mathrm{~s}$ in a homogenizer (Polytron PT 10-35 GT, Switzerland). The $\mathrm{pH}$ meter was calibrated daily with standard buffers of $\mathrm{pH} 4.0$ and 7.0 at $25^{\circ} \mathrm{C}$.

\section{Instrument color}

The surface color value of the jerky samples were measured by the CIE L*, a* and $b^{*}$ system using a Minolta chromameter(Model CR-410, Minolta Co. Ltd., Japan), with measurements standardized with respect to a white calibration plate $\left(\mathrm{L}^{*}=89.2, \mathrm{a}^{*}=0.921, \mathrm{~b}^{*}=0.783\right)$ after 30 min blooming at room temperature. Color measurements for each of three replicates were taken and the $L^{*}, a^{*}$ and $b^{*}$ value was recorded.

\section{Shear force measurement}

The Jerky samples were prepared a cubic form $(20 \times 20$ $\times 10 \mathrm{~mm}$ ) and heated during $90 \mathrm{~s}$ in electrical grill (Nova EMG-533, 1,400 W, Evergreen enterprise, Korea). Internal temperature of the samples during heating was $72 \pm$ $2^{\circ} \mathrm{C}$ and then cooled for $30 \mathrm{~min}$ at room temperature. Each sample was cut perpendicular to the longitudinal orientation of the muscle fiber with a Warner-Bratzler shear attachment on a texture analyzer (TA-XT2i, Stable Micro System Ltd., U.K.), and measured the maximum shear force (unit; $\mathrm{kg}$ ). Test and pre-test speeds were set at $2.0 \mathrm{~mm} / \mathrm{s}$. Post-test speeds were set at $5.0 \mathrm{~mm} / \mathrm{s}$. Data were collected and analyzed from the shear force values to obtain for the maximum force required to shear through each sample.

\section{2-thiobarbituric acid-reactive substance (TBARS)}

The TBARS of jerky samples were analyzed by the method described by the procedure of Ahn et al. (1998). A $2.5 \mathrm{~g}$ jerky sample was homogenized using a homogenizer (Polytron PT 10-35 GT, Kinematica Co., Switzerland) with $15 \mathrm{~mL}$ of distilled water for $2 \mathrm{~min}$ and then transferred to $100 \mathrm{~mL}$ falcon tube. One millilitre of solution was placed in test tubes and $50 \mu \mathrm{L}$ buylated hydroxytoluene $(7.2 \%$ in ethanol, $\mathrm{w} / \mathrm{v})$ and $2 \mathrm{~mL}$ thiobarbituric acid/trichloroacetic acid solution (20 mM TBA/15\%,w/v) were added to the tubes. The mixture was vortexed and then incubated in a $90^{\circ} \mathrm{C}$ boiling water bath for $15 \mathrm{~min}$ to develop color. The sample was cooled in cold water for $10 \mathrm{~min}$, and centrifuged for $15 \mathrm{~min}$ at $3,000 \mathrm{~g}$. The absorbance of the resulting supernatant solution was determined at $531 \mathrm{~nm}$ against a blank containing all the reagents minus the sample. One millilitre of distilled water was added to test tube and mixed with $2 \mathrm{~mL}$ of TBA/TCA solution for blank sample. The TBARS was determined in triplicate on each jerky product. The amount of color was measured in a UV spectrophotometer (T60 U., Karaltay Scientific Instruments Co., China). The results were expressed as mg malonaldehyde/kg sample.

\section{Microbiological analysis}

The jerky samples $(1 \mathrm{~g})$ were placed in $9 \mathrm{~mL}$ sterilized peptone water $(1 \%$ sterile peptone, w/v) in a sterile 
stomacher bag. Samples were then homogenized using a stomacher (Interscience BagMixers, USA) for 2 min and diluted with peptone water for a microbial count. One millilitre of stomached and serially diluted with saline solution by 10 -fold was plated in triplicates. The number of total aerobic bacteria counts and yeast/mold was counted with petrifilm (3M, USA) by plating the diluted samples onto plate count agar and incubating the plates at $35^{\circ} \mathrm{C}$ for $48 \mathrm{~h}$. Each microbial count was the mean of three determinations. Microbial colonies were counted and expressed as colony forming units per gram of sample (CFU/g).

\section{Sensory evaluations}

The sensory scores were evaluated independently by 8 trained sensory panelists for each sample after 10 days of storage using a nine-point hedonic scale, varying from dislike/weak extremely (score 1) to like/strong extremely (score 9). The mean value from three repeated measurements was determined.

\section{Statistical methods}

An analysis of variance were performed on all the variables measured using the General Linear Model (GLM) procedure of the SAS statistical package (SAS, 2008). The Student-Newman-Keul test $(p<0.05)$ was used to determine differences among the treatment means.

\section{Results and Discussion}

\section{Moisture contents and $\mathbf{a}_{\mathrm{w}}$}

Changes in moisture content and $\mathrm{a}_{\mathrm{w}}$ of beef jerky added with SH powder during storage are shown in Table 2. In the present experiment, drying process of beef jerky had finished when $\mathrm{a}_{\mathrm{w}}$ reached below 0.75 to be given under the similar drying condition between control and treatments. The moisture contents of $\mathrm{SH}$ and ascorbic acidadded samples were higher than the control $(p<0.05)$. Initial water activity $(0 \mathrm{~d})$ of $\mathrm{SH} 0.5 \%$ and $1.0 \%$ samples were lower than the control $(p<0.05)$. Jung et al. (1994) investigated that moisture content and water activity of jerky decreased during storage. Furthermore, Paterson et al. (1988) reported that a decrease in water activity of jerky during storage may be due to sodium compounds as component of curing agents. In the study of Chang et al. (1996), the water activity of jerky generally ranged from 0.65 to 0.90 . In this investigation, the water activity values of control and SH samples were very similar to the $\mathrm{a}_{\mathrm{w}}$ values of about 0.70 found by Torres et al. (1994) for the Charqui, a typical Brazilian meat product obtained by salting and sun-drying beef jerky under the similar condition. In general, commercial intermediate moisture foods have moisture contents of $17 \%$ to $25 \%$ (Chen et al., 2004; Jose et al., 1994; Jung et al., 1994) and similar results were obtained in this investigation. When producing jerky products, it is crucial to control the moisture contents because $a_{w}$ is closely related to moisture contents (Leistner, 1987). Jerky products need to have a stable $\mathrm{a}_{\mathrm{w}}$ to avoid changes in quality during storage (Yamaguchi et al., 1986).

\section{pH, TBARS, and shear force}

The $\mathrm{pH}$, TBARS and shear force values of beef jerky added with SH during storage are presented in Table 3.

Table 2. Moisture content and water activity of sun-dried Hanwoo beef jerky added with Salicornia herbacea during storage

\begin{tabular}{|c|c|c|c|c|}
\hline \multirow{2}{*}{ Treatment } & \multicolumn{3}{|c|}{ Storage (days) } & \multirow{2}{*}{ SEM $^{1}$} \\
\hline & 0 & 10 & 20 & \\
\hline \multicolumn{5}{|c|}{ Moisture (\%) } \\
\hline Control & $24.33^{\mathrm{b}}$ & $24.00^{\mathrm{a}}$ & $25.22^{\mathrm{a}}$ & 0.26 \\
\hline Salicornia herbacea $0.5 \%$ & $29.78^{\text {ay }}$ & $22.00^{\mathrm{bx}}$ & $20.56^{\mathrm{bz}}$ & 1.29 \\
\hline Salicornia herbacea $1.0 \%$ & $28.89^{\mathrm{ax}}$ & $24.55^{\text {ay }}$ & $21.67^{\mathrm{bz}}$ & 1.06 \\
\hline Ascorbic acid $0.5 \%$ & $29.00^{\mathrm{ax}}$ & $24.67^{\text {ay }}$ & $18.22^{\mathrm{cz}}$ & 1.58 \\
\hline SEM & 1.16 & 0.34 & 1.32 & \\
\hline \multicolumn{5}{|c|}{ Water activity } \\
\hline Control & $0.69^{\mathrm{b}}$ & $0.66^{\mathrm{c}}$ & 0.65 & 0.01 \\
\hline Salicornia herbacea $0.5 \%$ & $0.67^{\mathrm{cy}}$ & $0.70^{\mathrm{ax}}$ & $0.67^{y}$ & 0.01 \\
\hline Salicornia herbacea $1.0 \%$ & $0.64^{\mathrm{dy}}$ & $0.65^{\mathrm{cx}}$ & $0.66^{\mathrm{x}}$ & 0.00 \\
\hline Ascorbic acid $0.5 \%$ & $0.75^{\mathrm{ax}}$ & $0.68^{\text {by }}$ & $0.65^{z}$ & 0.02 \\
\hline SEM & 0.02 & 0.01 & 0.01 & \\
\hline
\end{tabular}

\footnotetext{
${ }^{1}$ Standard error of the means $(n=5)$

${ }^{a-d}$ Figures with different letters within the same column differ significantly $(p<0.05)$.

${ }^{\mathrm{x}-\mathrm{z}}$ Figures with different letters within the same row differ significantly $(p<0.05)$.
} 
The $\mathrm{pH}$ values of beef jerky were 5.36 to 5.88 . The $\mathrm{pH}$ value of SH jerky was significantly higher than the control at $0 \mathrm{~d}(p<0.05)$. On the other than ascorbic acid one was lower than the control. The high levels of $\mathrm{pH}$ value seem to be due to the denaturation in meat protein by heating and dehydration (Lee et al., 2004). Yang and Lee (2002) observed that the $\mathrm{pH}$ of commercial beef jerky samples was within the range of 5.4-5.8. Several studies have demonstrated that $\mathrm{pH}$ values of beef jerky samples decreased slightly during the storage periods (Okonkwo et al., 1992). According to Leistner (1987), spoilage of various dried meat products by mold growth can be inhibited or delayed by lowering $\mathrm{pH}$.

TBARS value is the most common indicator used to measure the degree of lipid oxidation in meat products (Chen et al., 2004). There were no significantly differences in TBARS value between the control and the treatments during 0 and $10 \mathrm{~d}$ of storage (Table 3 ). However, there were significant differences after storage of $20 \mathrm{~d}$. $\mathrm{SH}$ and ascorbic acid jerky showed significantly lower TBARS value than the control $(p<0.05)$. This may be due to the fact that the $\mathrm{SH}$ showed antioxidative and free radical scavenging activity (Chung et al., 2005). The findings of this study agree with Han and Kim (2003) noted that antioxidative effect of $\mathrm{SH}$ on the lipid oxidation of pork and it had twice as high antioxidative effect as sea salt and bamboo salt. Similarly, Han and Kim (2003) investigated that antioxidant activity by addition of $\mathrm{SH}$ was similar to the activity of ascorbic acid. The TBARS value of all jerky samples increased during storage, regardless of control and treatments $(p<0.05)$. It is normally accepted that TBARS value increases in meat with increasing storage time (Jung et al., 1994; Yang et al., 2009). Chen et al. (2004) noted that as water activity value decreases, there was a proportional increase of lipid oxidation and this is closely related to the presence of $\mathrm{NaCl}$ which acts as pro-oxidant (Torres et al., 1994). It is assumed that $\mathrm{SH}$ samples had influence in controlling the lipid oxidation of jerky from these results.

Texture in the jerky products has an important role in quality perception, and determines market attractiveness of this type of product (Konieczny et al., 2007). Shear force values of beef jerky samples added with $\mathrm{SH}$ powder during time are presented in Table 3 . There was no significant difference observed in shear force values at 0 and $20 \mathrm{~d}$ of storage, regardless of control and treatments. However, beef jerky with $1.0 \% \mathrm{SH}$ showed significantly lower shear force value than the control $(p<0.05)$. Yang et al., (2009) evaluated the shear force values decreased with storage time in beef jerky samples with air drying.

\section{Color measurements}

Color values of beef jerky added with SH powders during storage are shown in Table 4. Meat color is one of the

Table 3. pH, TBARS and shear force values of sun-dried Hanwoo beef jerky added with natural Salicornia herbacea during storage

\begin{tabular}{|c|c|c|c|c|}
\hline \multirow{2}{*}{ Treatment } & \multicolumn{3}{|c|}{ Storage (days) } & \multirow{2}{*}{$\mathrm{SEM}^{1}$} \\
\hline & 0 & 10 & 20 & \\
\hline \multicolumn{5}{|c|}{$\mathrm{pH}$} \\
\hline Control & $5.77^{\text {by }}$ & $5.82^{\text {axy }}$ & $5.84^{\mathrm{abx}}$ & 0.01 \\
\hline Salicornia herbacea $0.5 \%$ & $5.81^{\text {ay }}$ & $5.87^{\mathrm{ax}}$ & $5.86^{\mathrm{ax}}$ & 0.01 \\
\hline Salicornia herbacea $1.0 \%$ & $5.80^{\mathrm{abz}}$ & $5.88^{\mathrm{ax}}$ & $5.83^{\text {by }}$ & 0.01 \\
\hline Ascorbic acid $0.5 \%$ & $5.43^{\mathrm{cx}}$ & $5.42^{\mathrm{bx}}$ & $5.36^{\mathrm{cy}}$ & 0.01 \\
\hline SEM & 0.05 & 0.06 & 0.06 & \\
\hline \multicolumn{5}{|c|}{ TBARS (mg malonedialdehyde/kg) } \\
\hline Control & $0.69^{\mathrm{z}}$ & $1.14^{\mathrm{y}}$ & $1.66^{\mathrm{ax}}$ & 0.14 \\
\hline Salicornia herbacea $0.5 \%$ & $0.64^{\mathrm{z}}$ & $0.96^{\mathrm{y}}$ & $1.12^{\mathrm{bx}}$ & 0.07 \\
\hline Salicornia herbacea $1.0 \%$ & $0.61^{\mathrm{y}}$ & $0.97^{\mathrm{x}}$ & $1.06^{\mathrm{bx}}$ & 0.07 \\
\hline Ascorbic acid $0.5 \%$ & $0.66^{\mathrm{y}}$ & $1.08^{\mathrm{x}}$ & $1.25^{\mathrm{bx}}$ & 0.09 \\
\hline SEM & 0.01 & 0.03 & 0.08 & \\
\hline \multicolumn{5}{|c|}{ Shear force (kgf) } \\
\hline Control & 17.13 & $13.67^{\mathrm{ab}}$ & 16.00 & 1.21 \\
\hline Salicornia herbacea $0.5 \%$ & $14.07^{\mathrm{z}}$ & $16.23^{\text {axy }}$ & $16.87^{\mathrm{x}}$ & 0.57 \\
\hline Salicornia herbacea $1.0 \%$ & 12.17 & $13.30^{\mathrm{b}}$ & 13.83 & 0.48 \\
\hline Ascorbic acid $0.5 \%$ & 19.20 & $14.33^{\mathrm{ab}}$ & 16.47 & 1.65 \\
\hline SEM & 1.40 & 0.47 & 0.87 & \\
\hline
\end{tabular}

${ }^{1}$ Standard error of the means $(n=5)$

${ }^{a-c}$ Figures with different letters within the same column differ significantly $(p<0.05)$.

${ }^{\mathrm{x}-\mathrm{z}}$ Figures with different letters within the same row differ significantly $(p<0.05)$. 
Table 4. CIE color values of sun-dried Hanwoo beef jerky added with Salicornia herbacea during storage

\begin{tabular}{|c|c|c|c|c|}
\hline \multirow{2}{*}{ Treatment } & \multicolumn{3}{|c|}{ Storage (days) } & \multirow{2}{*}{ SEM $^{1}$} \\
\hline & 0 & 10 & 20 & \\
\hline \multicolumn{5}{|c|}{$\mathrm{L}^{*}$ value } \\
\hline Control & $32.05^{\mathrm{ax}}$ & $30.21^{\text {ay }}$ & $29.24^{\mathrm{bz}}$ & 0.42 \\
\hline Salicornia herbacea $0.5 \%$ & $30.60^{\mathrm{bx}}$ & $29.38^{\text {by }}$ & $30.58^{\mathrm{ax}}$ & 0.21 \\
\hline Salicornia herbacea $1.0 \%$ & $30.25^{\text {bx }}$ & $28.44^{\mathrm{cz}}$ & $29.23^{\text {by }}$ & 0.27 \\
\hline Ascorbic acid $0.5 \%$ & $28.58^{\mathrm{cx}}$ & $28.21^{\mathrm{cxy}}$ & $27.24^{\text {cy }}$ & 0.25 \\
\hline SEM & 0.39 & 0.25 & 0.36 & \\
\hline \multicolumn{5}{|c|}{$a^{*}$ value } \\
\hline Control & $15.76^{\mathrm{ax}}$ & $4.63^{\text {by }}$ & $4.84^{\text {ay }}$ & 1.84 \\
\hline Salicornia herbacea $0.5 \%$ & $8.72^{\mathrm{bx}}$ & $5.41^{\text {aby }}$ & $2.84^{\mathrm{bz}}$ & 0.86 \\
\hline Salicornia herbacea $1.0 \%$ & $6.95^{\mathrm{bx}}$ & $2.47^{\text {cy }}$ & $2.73^{\text {by }}$ & 0.76 \\
\hline Ascorbic acid $0.5 \%$ & $7.00^{b x}$ & $6.00^{\text {axy }}$ & $4.97^{\text {ay }}$ & 0.39 \\
\hline SEM & 1.12 & 0.42 & 0.33 & \\
\hline \multicolumn{5}{|c|}{$\mathrm{b}^{*}$ value } \\
\hline Control & $7.17^{\mathrm{ax}}$ & $3.98^{\text {by }}$ & $3.96^{\mathrm{cy}}$ & 0.54 \\
\hline Salicornia herbacea $0.5 \%$ & $5.15^{\mathrm{bx}}$ & $5.13^{\mathrm{ax}}$ & $4.44^{\text {by }}$ & 0.13 \\
\hline Salicornia herbacea $1.0 \%$ & $5.15^{\text {bx }}$ & $3.49^{\mathrm{bz}}$ & $4.48^{\text {ay }}$ & 0.25 \\
\hline Ascorbic acid $0.5 \%$ & $5.67^{b x}$ & $3.45^{\text {by }}$ & $3.90^{\mathrm{dy}}$ & 0.36 \\
\hline SEM & 0.27 & 0.22 & 0.08 & \\
\hline
\end{tabular}

${ }^{1}$ Standard error of the means $(n=5)$

${ }^{a-d}$ Figures with different letters within the same column differ significantly $(p<0.05)$.

${ }^{\mathrm{x}-\mathrm{z}}$ Figures with different letters within the same row differ significantly $(p<0.05)$.

most important quality traits and could be affected by a number of factors such as $\mathrm{pH}$, protein denaturation, and water content (Feiner, 2006; Young and West, 2001). The control samples showed a significantly higher lightness $\left(\mathrm{L}^{*}\right)$, redness $\left(\mathrm{a}^{*}\right)$ and yellowness $\left(\mathrm{b}^{*}\right)$ than $\mathrm{SH}$ samples at $0 \mathrm{~d}(p<0.05)$. SH samples showed a significantly lower redness $\left(\mathrm{a}^{*}\right)$ than control $(p<0.05)$. It is assumed that pigment isolated from the $\mathrm{SH}$ might be affected the meat color stability (Kim and Hong, 2011), which could be attributed to photochemical reaction of sun. Sherwin and Labuza (2003) showed that discoloration of jerky products could be affected by temperature. From the results, as the storage period increased, all treatments caused a significant decrease in $\mathrm{a}^{*}$ values $(p<0.05)$.

\section{Microbiological analysis}

Changes in total plate counts and yeast $/$ mold of beef jerky added with SH powder during storage are provided in Table 5. The total microbial counts of jerky were within a range of low level from 2.56 to $4.03 \mathrm{Log} \mathrm{CFU} / \mathrm{g}$ during storage. There were significant differences observed TPC during storage among control and treatments $(p<0.05)$. TPC of SH 1.0\% samples was the lowest among the treatment at $0 \mathrm{~d}(p<0.05)$. TPC of SH $0.5 \%$ and $1.0 \%$ samples was significantly lower than control after storage of 0 and $20 \mathrm{~d}(p<0.05)$. However, TPC of ascorbic acid samples was the lowest after storage of $20 \mathrm{~d}(p<0.05)$.
Lee and An (2002) reported that SH has antimicrobial effect. Yang and Lee (2002) investigated that TPC of domestic and imported commercial beef jerky was within 3 to 4 Log CFU/g range, which this finding was in correspondence to these criteria in this experiment. Microbial growth could deteriorate the meat and meat products quality. Jung et al. (1994) reported that TPC of beef jerky was within 4 to $5 \mathrm{Log} \mathrm{CFU} / \mathrm{g}$ range after storage of $3 \mathrm{wk}$, which this finding was in correspondence to these criteria in this experiment.

Yeast/mold was detected in control and SH samples after storage of 10 and $20 \mathrm{~d}$ in this experiment, but it was not in ascorbic acid. In general, $\mathrm{a}_{\mathrm{w}}$ below 0.70 is recommended to prevent mold growth (USDA-FSIS, 2011). Microbial growth could deteriorate the meat and meat products quality. The low microbial levels seem to be due to the fact that microbial growth is inhibited at low water activity (Hocking, 1988; Torres et al., 1994). It is speculated that the growth of microorganisms can be efficiently controlled and inhibited by additional drying, treatment of antimicrobial or organic acid and vacuum packaging and so on. Presently, there is no legal limit for total aerobic counts in dried preserving meats such as jerky products on standards for processing and ingredients specifications of livestock products in Korea (QIA Notification, 2011). Regulation in jerky should be established by government authority for meat safety limits. Additional re- 
Table 5. Total plate counts (TPC) and Yeast/ Mold of sun-dried Hanwoo beef jerky added with Salicornia herbacea during storage

\begin{tabular}{|c|c|c|c|c|}
\hline \multirow{2}{*}{ Treatment } & \multicolumn{3}{|c|}{ Storage (days) } & \multirow{2}{*}{$\mathrm{SEM}^{1}$} \\
\hline & 0 & 10 & 20 & \\
\hline \multicolumn{5}{|c|}{ TPC (Log CFU/g) } \\
\hline Control & $3.33^{\mathrm{az}}$ & $3.90^{\text {ay }}$ & $4.03^{\mathrm{ax}}$ & 0.11 \\
\hline Salicornia herbacea $0.5 \%$ & $3.06^{\mathrm{b}}$ & $3.87^{\mathrm{a}}$ & $3.98^{\mathrm{ab}}$ & 0.31 \\
\hline Salicornia herbacea $1.0 \%$ & $2.56^{\mathrm{cy}}$ & $3.87^{\mathrm{ax}}$ & $3.91^{b c x}$ & 0.15 \\
\hline Ascorbic acid $0.5 \%$ & $3.21^{\text {aby }}$ & $3.46^{\text {by }}$ & $3.88^{\mathrm{cx}}$ & 0.11 \\
\hline SEM & 0.09 & 0.06 & 0.02 & \\
\hline \multicolumn{5}{|c|}{ Yeast/Mold (Log CFU/g) } \\
\hline Control & $\mathrm{ND}^{2}$ & 0.67 & 1.67 & 0.31 \\
\hline Salicornia herbacea $0.5 \%$ & ND & 0.67 & 1.33 & 0.37 \\
\hline Salicornia herbacea $1.0 \%$ & ND & 0.67 & 1.33 & 0.37 \\
\hline Ascorbic acid $0.5 \%$ & ND & ND & ND & - \\
\hline SEM & - & 0.15 & 0.29 & \\
\hline
\end{tabular}

${ }^{1}$ Standard error of the means $(n=5)$.

${ }^{2}$ Not detected.

${ }^{\mathrm{a}-\mathrm{c}}$ Figures with different letters within the same column differ significantly $(p<0.05)$.

${ }^{\mathrm{x}-\mathrm{z}}$ Figures with different letters within the same row differ significantly $(p<0.05)$.

Table 6. Sensory evaluation ${ }^{1}$ of sun-dried Hanwoo beef jerky added with Salicornia herbacea at day 0

\begin{tabular}{cccccc}
\hline \hline Treatment & Color & Flavor & Tenderness & Juiciness & Acceptability \\
\hline Control & $6.67^{\mathrm{a}}$ & $5.67^{\mathrm{b}}$ & $5.67^{\mathrm{a}}$ & 5.33 & 5.33 \\
Salicornia herbacea $0.5 \%$ & $3.67^{\mathrm{b}}$ & $7.67^{\mathrm{a}}$ & $5.67^{\mathrm{a}}$ & 6.00 & 6.33 \\
Salicornia herbacea $1.0 \%$ & $2.67^{\mathrm{b}}$ & $7.67^{\mathrm{a}}$ & $5.33^{\mathrm{ab}}$ & 5.67 & 6.33 \\
Ascorbic acid $0.5 \%$ & $1.00^{\mathrm{c}}$ & $5.33^{\mathrm{b}}$ & $4.33^{\mathrm{b}}$ & 4.67 & 5.67 \\
SEM $^{1}$ & 0.65 & 0.38 & 0.22 & 0.23 & 0.19 \\
\hline
\end{tabular}

11: extremely bad $\sim 9$ : extremely good.

${ }^{2}$ Standard error of the means $(n=10)$.

${ }^{a, b}$ Figures with different letters within the same column differ significantly $(p<0.05)$.

search on the microbiological safety of the jerky is needed to control microbiological contamination by more antimicrobial additives or controlled process environment.

\section{Sensory evaluation}

The most important sensory attributes of jerky are texture, color and flavor, which are determined by the raw material and numerous technological factors (Albright et al., 2000). The sensory panels were convened to assess the effects on the color, flavor, juiciness, tenderness and overall acceptability of beef added with SH (Table 6). There were no significant differences observed in juiciness and acceptability of beef jerky. The SH jerky samples, however, showed significantly higher flavor scores than other samples $(p<0.05)$, which can be attributed to harmonious combination between the flavors of meat jerky and SH. Mills (2004) pointed out that Warner-Bratzler shear force values were highly correlated with overall tenderness of muscle. The addition of $\mathrm{SH}$ showed higher flavor scores than other samples. It is indicated that jerky samples added with SH seems to have superior microbial safety and lower lipid oxidation than conventional ones.

\section{Acknowledgements}

This research was supported by the Ministry of Agriculture, Food and Rural Affairs, Republic of Korea (2012) entitled as "Development of production technologies for high quality and nutritional values of beef in Hanwoo" (No. 311016-3).

\section{References}

1. Ahn. D. U., Olson, D. G., Jo. C., Chen. X., Wu. C., and Lee, J. I. (1998) Effect of muscle type, packaging, and irradiation on lipid oxidation, volatile production, and color in raw pork patties. Meat Sci. 49, 27-39.

2. Albright, S. N., Kendall, P. A., and Sofos, J. N. (2000) Sensory properties of beef jerky processed under various conditions. In Proceedings of IFT annual meeting, June 10-14, Dallas, TX, USA, Session 11.

3. AOAC (2000) Official methods of analysis. 17th ed, Association of Official Analytical Chemists, Gaithersburg, MD.

4. Bang, M. A., Kim, H. A., and Cho, Y. J. (2002) Hypoglycemic and antioxidant effect of dietary hamcho powder in streptozotocin-induced diabetic rats. J. Kor. Soc. Food Sci. Nutr. 31, 840-846. 
5. Calicioglu, M., Sofos, J. N., and Kendall, P. A. (2003) Influence of marinades on survival during storage of acid-adapted and non-adapted Listeria monocytogenes inoculated postdrying on beef jerky. Int. J. Food Microbiol. 86, 283-292.

6. Chang, F. S., Huang, T. C., and Pearson, A. M. (1996) Control of the dehydration process in production of intermediate moisture meat products: A review. Adv. Food Nutri. Res. 39, 71-114.

7. Chastain, M. F., Huffman, D. L., Hsieh, W. H., and Cordray, J. C. (1982) Antioxidants in restructured beef/pork steaks. $J$. Food Sci. 47, 1779-1782.

8. Chen, W. S., Lin, D. C., and Chen, M. T. (2004) Determination of quality changes throughout processing steps in Chinese-style pork jerky. Asian-Aust. J. Anim. Sci., 17, 700-704.

9. Choi, J. H., Jeong, J. Y., Han, D. J., Choi, Y. S., Kim, H. Y., Lee, M. A., Lee, E. S., Paik, H. D., and Kim, C. J. (2008) Effects of pork/beef levels and various casings on quality properties of semi-dried jerky. Meat Sci. 71, 278-286.

10. Cho, Y. S., Kim, S. I., and Han, Y. S. (2008) Effects of slander glasswort (Salicornia herbacea L.) extract on improvements in bowel function and constipation relief. Korean $J$. Food Sci. Technol. 40, 326-331.

11. Chung, Y. C., Chun, H. K., Yang, J. Y., Kim, J. Y., Han, E. H., Kho, Y. H., and Jeong, H. G. (2005) Tungtungmadic acid, a novel antioxidant, from Salicornia herbacea. Arch. Pharm. Res. 28, 1122-1126.

12. Feiner G. (2006) Color in fresh meat and in cured meat products. In: Meat products handbook: Practical Science and Technology. Feiner, G. (ed) Woodhead Publishing, Cambridge, UK, pp. 142-157.

13. Han, S. K. and Kim, S. M. (2003) Antioxidative effect of Salicornia herbacea L. grown in closed sea beach. J. Kor. Soc. Food Sci. Nutr. 32, 207-210.

14. Hocking, A. D. (1988) Mould and yeast associated with foods of reduced water activity: Ecological interactions. In: Food Preservation by Moisture Control. Seow, C. C. (ed.) Elsevier Applied Science, London, pp. 57-72.

15. Jose, F. S., Rafael, G., and Miguel, A. C. (1994). $a_{w}$ of Spanish intermediate moisture meat products. Meat Sci. 38, 341350 .

16. Jung, S. W., Baek, Y. S., Kim, Y. S., and Kim, Y. H. (1994) Quality changes of beef jerky during storage. Korean J. Anim. Sci. 36, 683-697.

17. Jo, C. J., Ahn, J. H., Chon, S. M., Lee, K. S., Bae, T. J., and Kang, D. S. (2002). Studies on pharmacological effects of glasswort (Salicornia herbacea L.). Korean J. Medicinal Crop Sci. 10, 93-99.

18. Kim, M. H. (1990) Effects of pretreatments prior to conventional dehydration on dried product quality. Biochem. Eng. J. 4, 30-38.

19. Kim, J. Y., Cho, J. Y., Ma, Y. K., Park, K. Y., Lee, S. H., Ham, K. S., Lee, H. J., Park, K. H., and Moon, J. H. (2010) Dicaffeoylquinic acid derivatives and flavonoid glucosides from glasswort (Salicornia herbacea L.) and their antioxidative activity. Food Chem. 125, 55-62.

20. Kim, M. H. and Hong, G. J. (2011) Qualities of soybean Dasik with added saltwort powder. Korean J. Food Culture. 26,
501-505.

21. Kim, Y. A., Kong, C. S., Lee, J. I., Kim, H., Park, H. Y., Lee, H. S., Lee, C., and Seo, Y. (2012) Evaluation of novel antioxidant triterpenoid saponins from the halophyte Salicornia herbacea. Bioorganic Medicinal Chem. Letters. 22, 4318-4322.

22. Konieczny, P., Stangierski, J., and Kijowski, J. (2007) Physical and chemical characteristics and acceptability of home style beef jerky. Meat Sci. 76, 253-257.

23. Labelle, R. L. and Moyer, J. C. (1966) Dehydrofreezing red tart cherries. Food Technol. 20, 1345-1352.

24. Lee, J. T. and An, B. J. (2002) Detection of physical activity of Salicornia herbacea. Kor. J. Herbology 17, 61-69.

25. Lee, Y. S., Lee, H. S., Shin, K. H., Kim, B. K., and Lee, S. (2004) Constituents of the halophyte Salicornia herbacea. Arch. Pharm. Res. 27, 1034-1036.

26. Lee, K. S., Lee, M. H., Chang, I. Y., Yoon, S. P., Lim, D. Y., and Jeon, Y. J. (2006) Marcrophage activation by polysaccharide fraction isolated from Salicornia herbacea. J. Ethnopharmacol. 103, 372-378.

27. Leistner, L. (1987) Shelf stable product and intermediate moisture foods based on meat. In: Aw theory and application to food. Rockland, L., and Beuchat, L.B. (eds.) Marcel Dekker, Inc., NY, pp. 295-328.

28. Mills, E. (2004) Functional meat products. In: Encyclopedia of Meat Sciences. Jensen, W. K., Devine, C., and Dikeman, M. (eds) Elsevier, Oxford, pp. 1-6.

29. Okonkwo, T. M., Obanu1, Z. A., and Ledward, D. A. (1992) Characteristics of some intermediate moisture smoked meats. Meat Sci. 31, 135-145.

30. Park, C. J., Kim, M. L., and Park, C. S. (2009) Effect of drying method and medicinal herb extract addition on the microstructure of beef jerky. Korean J. Food Preserv. 16, 875-883.

31. Paterson, B. C., Parrish, F. C., and Stromer, M. H. (1988) Effect of salt and pyrophosphate on the physical and chemical properties of beef muscle. J. Food Sci. 53. 1258-1265.

32. QIA Notification. (2011) Standards for processing and ingredients specifications of livestock products, Quarntine and Inspection Agency.

33. Rababah, T. M., Hettiarachchy, N. S., and Horax, R. (2004) Total phenolics and antioxidant activities of fenugreek, green tea, black tea, grape seed, ginger, rosemary, gotu kola, and ginkgo extracts, vitamin $\mathrm{E}$, and tertbutylhydroquinone. $J$. Agric. Food Chem. 52, 5183-5186.

34. Shin, K. S., Boo, H. O., Jeon, M. W., and Ko, J. Y. (2002) Chemical constituents of native plant, Salicornia herbacea. Korean J. Plant Res. 15, 216-220.

35. SAS (2008) SAS/STAT Software for PC. Release 9.2, SAS Institute Inc., Cary, NC, USA.

36. Sherwin, C. P. and Labuza, T. P. (2003) Role of moisture in maillard browning reaction rate in intermediate moisture foods: Comparing solvent phase and matrix properties. J. Food Sci. 68, 588-594.

37. Torres, E. A. F. S., Shimokomaki, M., Franco, B. D. G. M., Landgrafa, M., Carvalho, B. C., and Santos, J. C. (1994) Parameters determining the quality of charqui, an intermediate moisture meat products. Meat Sci. 38, 229-234.

38. Department of Agriculture-Food Safety and Inspection Ser- 
vice (2011) Jerky and Food safety. Food Safety and Inspection Service, United States Department of Agriculture, Washington, DC, USA. Available from: http://www.fsis.usda.gov/Fact Sheets/Jerky_and_Food_Safety/index.asp\#1. Modified Nov. 15, 2011.

39. Yamaguchi, N., Naito, S., Okada, Y., and Nagase, A. (1986) Effect of oxygen barrier of packaging material on food preservation. Annual Report of the Food Research Institute, 27. Japan: AichiPrefecture Government. pp. 69-73

40. Yang, C. Y. and Lee, S. H. (2002) An evaluation of quality of the marketing jerky in domestic. I. Investigation of outward appearance, food additives, nutrient content and sanitary state. Korean J. Food and Nutri. 15, 197-202.

41. Yang, H. S., Hwang, Y. H., Joo, S. T., and Park. G. B. (2009) The physicochemical and microbiological characteristics of pork jerky in comparison to beef jerky. Meat Sci. 82, 289294.

42. Young, O. A. and West, J. (2001) Meat color. In: Meat Science and Applications. Hui, Y. H., Nip, W. K., and Rogers, R. (eds) Marcel Dekker, Inc., NY, pp. 39-69.

(Received 2013.1.21/Revised 2013.3.4/Accepted 2013.3.26) 